\title{
Evidence that cultural food practices of Adi women in Arunachal Pradesh, India, improve social-ecological resilience: insights for Sustainable Development Goals
}

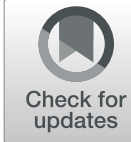

Ranjay K. Singh ${ }^{1,2^{*}}$, Arvind Kumar ${ }^{2}$, Anshuman Singh ${ }^{2}$ and Poonam Singhal ${ }^{3}$

\begin{abstract}
Introduction: Sustainable use of biocultural diversity can help achieve Sustainable Development Goals (SDGs) in many ways. The tribal communities of bio-culturally rich Northeastern India rely heavily on local food resources and knowledge for livelihood security. In this study with Adi women of East Siang district, Arunachal Pradesh, India, we aimed to understand (i) access and use patterns for biocultural plants and animal species from diverse ecosystems and (ii) species diversity and conservation strategies deployed by Adis. We employed a novel participatory approach called "recipe contest" to mobilize Adi women from 15 randomly selected remote and transitional villages. Data collected through interviews, focus group discussions and transect walks from 75 women, were analyzed using qualitative and quantitative methods.
\end{abstract}

Results: We found that traditional local food was linked intricately with women's knowledge, access patterns, and socio-cultural institutions. From an end-user perspective, remote Adi villages had more widespread use of plant species (14 as food; 34 as food-cum-ethnomedicine and 13 as income-generating species) and animal (17) as food in remote than in transitional villages. Further, there were significant differences ( $p<0.000 ; 0244$ and 0.000, respectively) across the social groups for use of plant- and animal-derived food and ethnomedicine. Among different land use systems (i.e., Jhum lands, home gardens, and morang forests), the highest diversity for food plant was found in home gardens while that for food-cum-ethnomedicinal plants and animal species was observed in morang forests. Adi women apply traditional agronomic, cultural, and harvest strategies, based on local knowledge and institutions and varying with social systems, to conserve their key local resources. Significant correlations $(r=$ 0.63 to 0.92 ) were seen between conservation and use of food and animal species. Traditional knowledge on these aspects was linked intricately to the socio-cultural milieu and is transmitted inter-generationally through various social institutions.

Conclusions: Cultural food practices, crucial to social-ecological resilience and livelihood security of Adi and similar indigenous communities confronting global environmental challenges, need to be mainstreamed with relevant policies for achieving some targets of SDGs.

Keywords: Adi women, Arunachal Pradesh, Conservation, Diverse ecosystems, SDGs, Traditional food species

\footnotetext{
*Correspondence: ranjaysingh_jbp@rediffmail.com

${ }^{1}$ College of Horticulture and Forestry, Central Agricultural University, Pasighat, Arunachal Pradesh 791102, India

${ }^{2}$ ICAR-Central Soil Salinity Research Institute, Karnal, Haryana 132001, India

Full list of author information is available at the end of the article
}

\section{Springer Open}

(c) The Author(s). 2020 Open Access This article is licensed under a Creative Commons Attribution 4.0 International License, which permits use, sharing, adaptation, distribution and reproduction in any medium or format, as long as you give appropriate credit to the original author(s) and the source, provide a link to the Creative Commons licence, and indicate if changes were made. The images or other third party material in this article are included in the article's Creative Commons licence, unless indicated otherwise in a credit line to the material. If material is not included in the article's Creative Commons licence and your intended use is not permitted by statutory regulation or exceeds the permitted use, you will need to obtain permission directly from the copyright holder. To view a copy of this licence, visit http://creativecommons.org/licenses/by/4.0/. 


\section{Introduction}

Human-environment interactions shape socio-cultural and ecosystem diversity in several ways (Marten 2001). Social-ecological diversity, in turn, helps determine intrinsic relations between food-based cultures and livelihood patterns (Pretty et al. 2009). Learning about local biodiversity-based traditional food systems requires continuous acquisition and integration of knowledge from diverse sources (Turner and Turner 2004; Reyes-García et al. 2009). Such knowledge varies with eco-cultural diversity and local strategies for accessing food-based resources (Singh et al. 2010). In the recent past, erosion of traditional food and related cultural knowledge, and the importance of characterizing, validating, and promoting this knowledge has been stressed, particularly relating to impacts on peoples' nutrition and health (Kuhnlein 2005; Kuhnlein et al. 2013; Turner 2005). Mainstream society can learn from traditional knowledge holders to better understand and strengthen location-specific adaptive practices for sustaining biocultural diversity and reducing land degradation (Pretty et al. 2009).

Women are generally considered more knowledgeable than men regarding the ecology and conservation practices of plants used as food and ethnomedicine (Merétika et al. 2010), since they need this knowledge for ensuring family food security (Ellena and Nongkynrih 2017). In mountainous regions in particular, where subsistence economies prevail, strategies for food production and sustenance are major responsibilities of women (Singh et al. 2017), who possess significant knowledge of harvesting, processing, and use of food and ethnomedicine (Magni 2016). Women in general also play an important role in intergenerational transfer of traditional knowledge (TK), thus ultimately assuring food and livelihood security, as well as careful observation and testing of particular foods (Turner and Clifton 2009; Turner and Spalding 2013). Women's knowledge of processing and sustaining food and nutritional resources varies with socio-cultural systems (Gupta 1996).

Arunachal Pradesh (Ar P), a state in northeastern India, occupies $7.7 \%$ of the total geographical area of the country and is one of the biodiversity hot-spots of the world (Myer et al. 2000). It harbors a large proportion of India's flora [(8000 species) (Rao 1994)], with about 4\% (2526 plant species) being endemic (Nayar 1996). Community forests-which include forests under clan control, cultivated and non-cultivated floras in jhum land (slash and burn agriculture), and home gardens-play a pivotal role in conservation of indigenous biodiversity and securing food and livelihoods for local communities (Ramakrishnan 2007). In Ar P, the women often take the lead in managing TK, and in development, care, and well-being of families and their food systems. However, in most conservation programs for biodiversity of
India-including Ar $\mathrm{P}$-the roles of women and their knowledge for strengthening and promoting community survival are often not acknowledged (Mishra et al. 2009). An understanding of women's roles and the ways in which they uphold TK-either in harvesting or adding cultural value to plants and animals used as food and ethnomedicine-and in conservation of related biodiversity is critical to achieving some of the SDGs (Sustainable Development Goals) in India. This study focuses on the Adi women of Ar P relating to understand (i) access of culturally valuable local plant and animal species from diverse ecosystems for use as food and ethnomedicine and (ii) assessing species diversity and location-specific traditional conservation strategies.

\section{Conceptual framework}

Tribal communities living in remote locations of India, particularly of mountainous ecosystems differ from those of more settled and manipulated landscapes in terms of available resources and socio-cultural and political resource base (Joshi 1989) (Fig. 1). These economically marginal communities, unable to access external resources, have developed ecosystem-based knowledge systems (Gupta et al. 1999; Subramanian and Pisupati 2010), to survive and maintain biocultural diversity (Toledo 1999). Over time, they have also evolved culturally and ecologically responsive strategies for adapting to multiple stressors (Davidson-Hunt et al. 2012). Identifying these strategies can provide meaningful insights for policymakers attempting to develop place-based approaches to land and resource use, and meeting targets of SDGs, especially for biocultural hot-spots (Maffi 2010; UNESCO 2019). Based on insights from Toledo (1999), Maffi (2010), and Davidson-Hunt et al. (2012), we conceptualized Adi biocultural resources as "a plantanimal-cultural continuum contributing to resilience and sustainable livelihoods".

Development approaches relating to food and environmental security for those having predominant biocultural resource bases require a different lens for understanding people's worldviews and practices for sustainability (Davidson-Hunt et al. 2012). The Indian government has prepared a stakeholder framework to meet the SDG targets (particularly goal 1, "No Poverty"; goal 2, "Zero Hunger"; and goal 15, "Life on Land") (Aayog 2017). Scrutiny of this framework, however, shows a lack of focus on SDGs on ensuring biocultural resources and inclusion of bottom-up perspectives from marginal and tribal communities. Schleicher et al. (2018) stress the importance of biocultural diversity in understanding the constraints of such peoples and their priorities and agendas. We have conceptualized biocultural knowledge as how tribal communities assign cultural values to local plant and animal species used as traditional foods and 


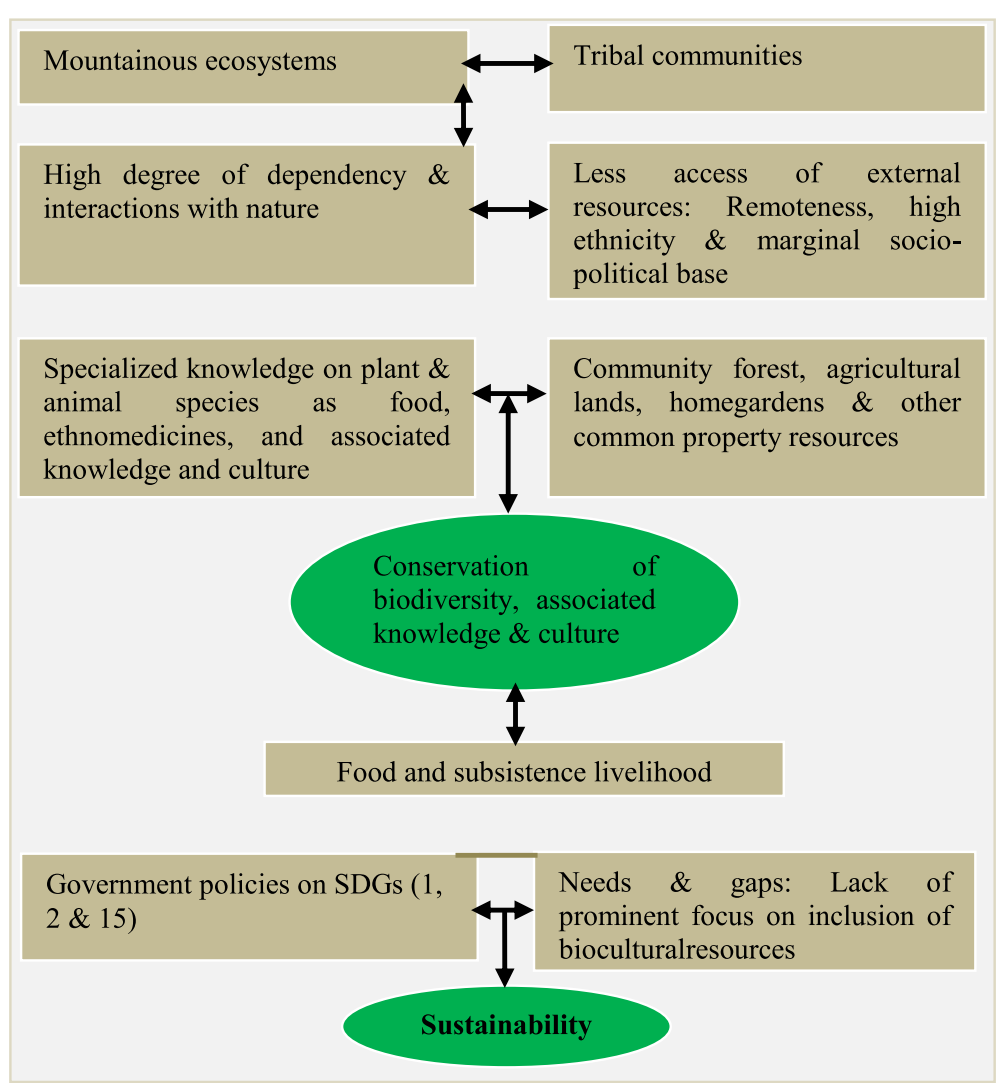

Fig. 1 Conceptual framework on biocultural resources helping to sustain food security and subsidence livelihood, and contributing to the Sustainable Development Goals

how they apply their knowledge to access, use, and conserve these species in diverse ecosystems (Fig. 1). We assumed that inclusion of insights from the biocultural resources conserved by more nature dependent and marginal communities (in our case Adi) in making strategies on SDGs can provide multiple-scale outcomes helpful in addressing the challenges of SDGs (Fig. 1).

In this study, we documented Adi food species, their origins, use as food and/or ethnomedicine, and importance in local culture including beliefs, festivals, and marriage (Maffi 2010). We also documented Adi women's traditional management practices, growing and maintaining local species in particular land use types (Fig. 1). We first present Adi women's use and access patterns for local plant and animal species as food, ethnomedicine, and income provisions and how these vary in remote and transitional villages. We then highlight similarities and differences in food species and document how different traditional agronomic and cultural practices can strengthen conservation of these species within different social systems. Finally, we highlight connections between culture, learning (biocultural dimensions), and food species conservation. We discuss probable determinants shaping the key trends reflected in our results, and suggest how policy and planning agencies can gain insights to strengthen some targets of SDGs relevant to fragile mountainous ecosystems.

\section{Research methodology \\ Study area}

Arunachal Pradesh (Ar P) state of India $\left(26^{\circ} 28^{\prime}\right.$ and $29^{\circ}$ $30^{\prime} \mathrm{N}, 90^{\circ} 30^{\prime}$ and $97^{\circ} 30^{\prime} \mathrm{E}$ ) covers an area of $83,743 \mathrm{~km}^{2}$. The entire state is mountainous, with altitudes ranging from 200 to $6,400 \mathrm{~m}$ above sea level. The climate is humid at lower elevations; the valleys are covered by swampy rainforest, particularly in the eastern section. Altogether, the state's forest cover is $81.22 \%$. Forests comprise $10.03 \%$ of India's total forest cover (DoEF 2010). Most of "unclassified" forests in Ar P are morang (community owned). Forests in and around jhum lands are managed by particular clans/tribes (Singh et al. 2018).

Ar P is home to 26 tribes and about 110 ethnic groups. The Adi (also known as Abor) are a major collective tribe living in West Siang, East Siang, Upper Siang, Upper Subansiri, and Dibang Valley districts. The Adi have distinct customs, dialect, and life-ways (Danggen 2003). Their economy is primarily agrarian, revolving predominantly around jhum and wet rice cultivation. 
Their staple foods include rice, maize, millets, and forest-based traditional food products. Women collect culturally important plants from diverse ecosystems for their food, ethnomedicine, marketing, firewood, and other needs. Men hunt wild game from morang community forests, including for feasting on cultural occasions such as festivals and weddings (Singh et al. 2010). A traditional measure of a family's wealth is the possession of "mithun," a native ox (Bos frontalis). Folk dances are performed as part of important rituals, during festivals and other occasions, generally accompanying serving of traditional foods.

\section{Research design}

Exploratory research design is widely applied in assessing human-environment interactions to develop a better understanding of how people perceive and use local resources for their well-being (Cuthil 2002). The purpose of this research was to explore the culturally valuable plant and animal species being used as food and/or ethnomedicine and for income generation, and how they are being conserved by the Adis. We used an exploratory research design (Roscoe 1975) involving both conventional social-ecological tools and unique participatory approaches (Wagner and Alexander 2013) to accomplish the study objectives (Fig. 2).

\section{Sampling of study area}

We applied a mixed method of sampling to the study area (Onwuegbuzie and Collins 2007). At the outset, we approached each village community, building rapport with key village communicators (customary chief, elders, cultural experts and hunters) to describe our study objectives. The study was carried out within three purposively selected circles (State Government administrative units): Pasighat and Mebo of East Siang, and Maryang of Upper Siang. This purposive selection was based on Adi's ethnicity, high dependency on local bioresources, remoteness of the region, high level of diversity and endemism of plant resources (both terrestrial and aquatic), and communal nature of the local resources. Within each circle, five villages (a total of 15 from three circles) were selected randomly. Seven of these were relatively remote and 8 were transitional, being situated closer to towns.

\section{Recipe contest: participatory methodology for sampling participants}

In each sampled village, a participatory recipe contest (traditional food competition) was organized among Adi women, being publicized about 15 days prior to the event. Potential women participants were informed about the event with the help of a team, consisting of Gaon Burha (customary chief of an Adi village), elders

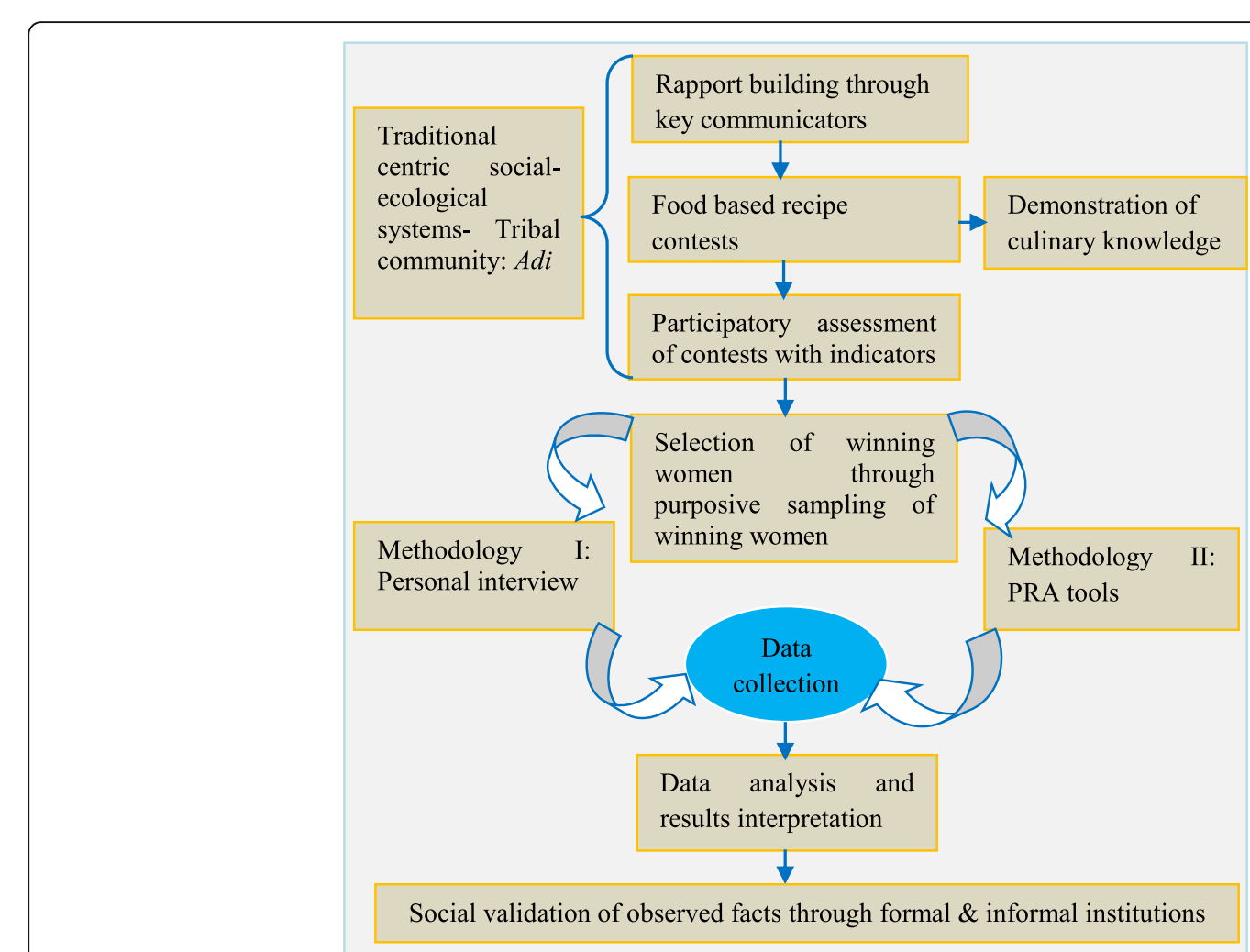

Fig. 2 Schematic presentation of exploratory research methodology 
and hunters of selected villages. The contest allowed us to explore, fairly readily, each village's relative diversity of culturally important plant- and animal-based traditional food (Singh and Singh 2013). On a fixed date, interested women presented dishes prepared from local plants and animals in village mosup (community hall) (Fig. 3), along with plant samples and dried parts of animals (stored already). Their plant samples were identified by plant taxonomists of the Botanical Survey of India, Ar P and zoological resources were identified by wildlife experts, with the help of hunters and the participating women.

The number of participants in the selected villages varied from 15 to 35. The plant- and animal-based foods were assessed by a team consisting of 4-5 elderly women, Gaon Burha ( 4; 60 from 15 villages) and study team members. Assessment categories included local species used as food, traditional cooking methods applied, learning sources (parents, grandparents, or other members of community), and knowledge about the ecosystems from which species were accessed. Each category was assigned a potential high score of "1"; thus, a species fulfilling all criteria would be assigned a maximum score of "4." Based on the highest mean scores (scores assigned from village food expert and scientists added together) obtained by women for their total foods presented in the "recipe contest," first, second, and third prizes were awarded, with two additional consolation prizes. The winners received their awards at a public gathering in each village, and the proceedings were broadcasted by All India Radio, Pasighat (East Siang district). Based on scores obtained in the contest, a total of 35 women were finally selected randomly (based on the equal probability to each participant of being selection) from remote villages and 40 from transition villages. Thus, we interviewed a total of 75 women (five from each village) for recording study observations (see Additional file 1: Table S1).

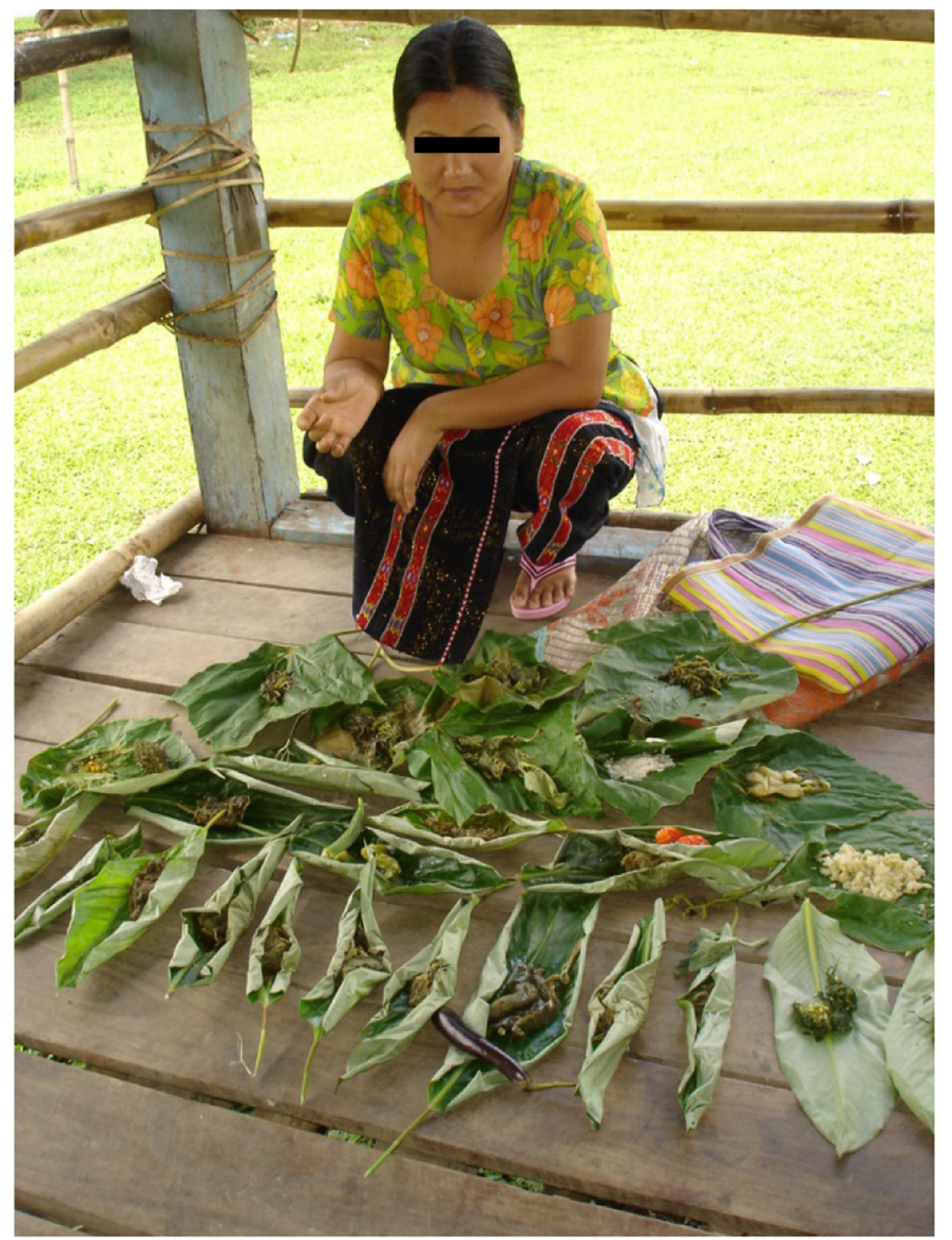

Fig. 3 An Adi woman displaying diversity of traditional food prepared from local plant and animal species (photo by Ranjay K. Singh) 


\section{Data collection through interviews}

Our interview schedule with open-ended questions was based on a local literature search and scopic study (Orchard et al. 2016) conducted earlier (Singh and Adi 2010), allowing us to become familiar with the local context. We applied a combination of data collection approaches, both qualitative (use and access patterns of species, agronomic practices and cultural dimensions) and quantitative (diversity of plant species, conservation practices and income). The interview schedule was first applied in a pilot test with 5 Adi women in a nonsampled area to assess the reliability of our questionnaire and make any needed improvements in questions and language (see Additional file 1: Table S2). Throughout the study a local guide assisted us in our documentation, and the women participants were interviewed in the Adi dialect. On average, interviews were conducted in segments over 1-2 days per woman, with a total of about one week of interviewing for each village.

\section{Data collection through participatory tools}

Transect walks were done with elders and sampled respondents to identify land use types. Visits to various food production and conservation areas (jhum lands, home gardens, morang community forest, and aquatic bodies under common property resources) were made, with the support of village elders (4 per village), who helped in our assessments during the recipe contests, recording and validating the different food species (see Additional file 1: Table S3). Focus group discussions helped to document complex aspects such as changes in food systems over time, cultural dimensions and a deeper sense of ecological aspects of food species. Participant observations with some respondents helped to document agronomic and harvesting practices and connections between festivals and traditional foods. Participatory audio recording helped to cross check data taken through interviews and FGD (see Additional file 1: Table S4).

\section{Measurement of major variables}

Learning modes were assessed in terms of number of socio-cultural institutions (e.g., family and indigenous institutions) through which respondents acquired local knowledge of plant and animal species. Land use systems (home gardens, jhum land, morang community forest and water stream or community river) determined scores assigned to a species: 1 for species conserved in home gardens (less in area), 2 for those in jhum land (moderately higher in area), and 3 for species conserved in morang forests or water streams (highest in area). The conservation of each species was considered based on their cultivation within a particular land use type or how the Adi women allowed them to grow naturally (prefixing cultural value). The food species included in this study were classified based on the purpose of use and access from different land use types. Use, as a variable, was quantified by assigning a score of "1" if a species was used by less than $50 \%$ of respondents, followed by " 3 " (51-75\%) and "5" (76-100\%). This score also helped in assessing significance of difference between two social groups about species used for diverse purposes. Similar patterns were followed in species used both in food and ethnomedicines, and those used as animal-based food.

\section{Criteria for selection of species for economic and livelihood aspects}

Data were collected for 13 of the most popular ethnobotanicals and their overall economic value was assessed using the following criteria: (i) most frequently used in foods, (ii) easy availability, (iii) conservation in various habitats, (iv) economic value in local market, and (v) adaptive capacity for climatic, ecological, and socioinstitutional stresses.

\section{Data analysis and statistics}

A thematic technique was applied to determine patterns and trends in particular aspects of the data (Stringer et al. 2017). Diversity indices of species found in different land use systems were calculated drawing on insights from Coddington et al. (1996), Camargo (1997), Nagendra (2002) and Eguia-Aguilara et al. (2005). The indices were computed using PAST software (Hammer et al. 2001). STAR statistics (version 2.0.1) (IRRI 2013) was applied to compute the Spearman correlation between usage and conservation of species. The significance of difference between usage of plant and animal food species and income of women from remote and transitional villages was tested applying $t$ test. Other data, including use percentage, income, and agronomic practices, were analyzed using descriptive statistics in a spreadsheet. Key results obtained were shared back with the study respondents to socially validate our conclusions.

\section{Results \\ Use and accessibility of food species \\ Plant food species}

Fourteen plant species were identified as key ingredients in the foods prepared by Adi women. The percentage of use of plant species as food varied from as low as $50.4 \%$ for dilap (Allium hookeri) to the highest at $97.7 \%$, for onger (Zanthoxylum rhetsa) in remote villages (Table 1). These two species were used relatively less in transitioning villages (55.8 and 25.0\%, respectively). Marshang (Spilanthes acmella) was the second most used species in remote villages (94.6\%), while ongin was used highly (65.0\%), followed by marshang, by the respondents of 
Table 1 Major local plants species used in foods

\begin{tabular}{|c|c|c|c|c|c|}
\hline \multirow[t]{2}{*}{ Local name } & \multirow[t]{2}{*}{ Botanical name } & \multirow[t]{2}{*}{ Parts used ${ }^{a}$} & \multirow[t]{2}{*}{ Habitats $^{b}$} & \multicolumn{2}{|c|}{ Use $\%^{c}$} \\
\hline & & & & Rural & Transitioned village \\
\hline Lai saag & Brassica sp. L. & Leaf & $J \mathrm{~L}$ and $\mathrm{HG}$ & 65.9 & 50.5 \\
\hline Dilap & Alleum hookeri L. & Whole plant & $J$ and $H G$ & 50.4 & 25.0 \\
\hline Epuk-tangum & Bidens pilosa $\mathrm{L}$. & Leaf & $J$ and $H G$ & 87.5 & 40.5 \\
\hline Onger & Zanthoxylum rhetsa (Roxb.) DC. & Leaf & $J, H G$, and MCF & 97.7 & 55.8 \\
\hline Ongin & Clerodendrumcole brookianum Walp. & Leaf & $J \mathrm{~L}, \mathrm{HG}$, and MCF & 93.9 & 65.0 \\
\hline Marshang & Spilanthes acmella L. & Leaf & $J \mathrm{~L}, \mathrm{HG}$, and MCF & 94.6 & 58.0 \\
\hline Kopi & Solanum khasianum C.B. Clarke & Fruits & $J \mathrm{~L}$ and $\mathrm{HG}$ & 80.5 & 47.0 \\
\hline Koppir & Solanum spirale Roxb. & Fruits & $J \mathrm{~L}$ and $\mathrm{HG}$ & 60.3 & 41.4 \\
\hline Paput & Gnaphalium affine D. Don & Leaf & $J \mathrm{~L}$ and $\mathrm{HG}$ & 59.1 & 20.2 \\
\hline Mamang & Physalis minima $\mathrm{L}$. & Leaf & $J \mathrm{~L}$ and $\mathrm{HG}$ & 58.4 & 15.0 \\
\hline Fayong & Polygonum chinensis Meissn. & Leaf & $J \mathrm{~L}$ and $\mathrm{HG}$ & 68.9 & 10.5 \\
\hline Nayang & Erigeron Canadensis L. & Leaf & $J \mathrm{~L}, \mathrm{HG}$, and MCF & 91.2 & 35.7 \\
\hline Tangum & Bidens pilosa L. & Leaf & $J \mathrm{~L}$ and $\mathrm{HG}$ & 68.6 & 19.0 \\
\hline Gende & Gynura crepidioides Benth & Leaf & $J \mathrm{~L}$ and $\mathrm{HG}$ & 86.8 & 38.4 \\
\hline Statistics & & & $t$ value $=5.36, p$ & & \\
\hline
\end{tabular}

IL Jhum-land, HG home gardens, MCF Morang community forest

aplant parts data: 11 species as leaves (78.57\%), 2 species each as fruit (14.28\%), 1 species as whole plant (7.14\%)

${ }^{\mathrm{b}}$ Species data: $\mathrm{JL}$ and HG $=10$ species $(71.42 \%) ; \mathrm{JL}, \mathrm{HG}$, and MCF 4 species $(28.57 \%)$

'Multiple percentages

transition villages. Overall, women from remote villages used a greater percentage of local plant species as food than their counterparts of transition villages and these two groups varied significantly $(t=5.36, p<0.000)$. Out of 14 , most of the species were used in the form of leaves $(78.57 \%)$ and fruits $(14.28 \%)$ across the social systems. The majority $(71.42 \%)$ of the food plant species were accessed from jhum lands and home gardens, and the remainder from a set of three land use systems: jhum lands, home gardens, and morang community forests (28.57\%).

\section{Food plant species with ethnomedicinal values}

We identified 33 plant species used as both food and ethnomedicine for treating certain diseases and disorders (Table 2). Namdung (Perilla ocymoides) was recorded to be a highly used dual purpose species (for stomach disorders and supplementary food for pregnant women) by Adi women of remote villages (97.5\%), but somewhat lower among women of transition villages (58.5\%). Gende (Gynura crepidioides) was the second most used species, for both remote and transitional Adi women ( $96.6 \%$ and $41.5 \%$, respectively), for curing sickness. Overall, based on a total of 33 species, the dependency of women from remote villages on use of plants as food and ethnomedicine was significantly greater than those of their transitional village counterparts $(t=5.11, p<$ $0.000)$. Leaves $(45.45 \%)$ and fruits $(27.27 \%)$ of these species were the most usable parts across both the social systems. Home gardens were the most accessed land use system (45.45\%), followed by jhum lands (24.24\%) and morang community forests (30.30\%) for dual purpose species.

In terms of medicinal species, some like kekir or ginger (Zingiber siangensis) and oik (Pouzolzia hirta), were used for coughs and colds, and for treating snake bites and improving lactation among mothers, respectively. However, their use varied between remote $(85.5 \%)$ and transition villages $(57.8 \%)$. Some local medicinal species were also sometimes prescribed by professional doctors, according to our interviewees. For example, ongin (Clerodendrum colebrookianum) is recommended for controlling diabetes and high blood pressure $(35.8 \%$ in remote and $39.8 \%$ in transitioning villages). Similarly, the green leaves of onger (Zanthoxylum rhetsa), rich in antioxidants (Bhardwaj et al. 2005), are used in controlling dysentery and diarrhea (66.8 \% in remote and $45.7 \%$ in transitioning villages). Onger leaves are also cooked with pork and other meats (as are other leafy vegetables), to improve the taste and reduce the incidence of potential parasitic diseases like tapeworm infestation (Yadav and Tangpu 2009).

\section{Animal-based food species}

A total of 17 wild animal, fish and insect species were found to be traditional Adi foods (Table 3). Ngopi (Labeo dero) and ghongha (Lymnaea sp.)/snails (various indigenous species) were used by almost every woman (100\%) in remote villages, while having relatively lower use (60.5 and 
Table 2 List of major ethnobotanicals used as food-cum-ethnomedicine by the Adi women

\begin{tabular}{|c|c|c|c|c|c|c|}
\hline \multirow[t]{2}{*}{ Local name } & \multirow[t]{2}{*}{ Botanical name } & \multirow[t]{2}{*}{ Part used ${ }^{a}$} & \multirow[t]{2}{*}{ Habitats $^{b}$} & \multirow[t]{2}{*}{ Disease/disorders/ailments } & \multicolumn{2}{|c|}{ Percentage of use ${ }^{c}$} \\
\hline & & & & & $\begin{array}{l}\text { Remote } \\
\text { villages }\end{array}$ & $\begin{array}{l}\text { Transitioned } \\
\text { villages }\end{array}$ \\
\hline Amta & Hibiscus sabdariffa L. & Flowers and leaves & $J$ & Diarrhea and dysentery & 95.2 & 21.0 \\
\hline Bangko & Solanum spirale Roxb. & Leaves and fruits & $J$ & High blood pressure and diabetes & 94.6 & 32.5 \\
\hline Kordoi & Averrhoa carambola L. & Fruits & MCF & Jaundice & 24.2 & 8.0 \\
\hline Champa & Dillenia indica L. & $\begin{array}{l}\text { Peel of fruit with } \\
\text { small fishes }\end{array}$ & MCF & Stomach pain & 22.4 & 6.5 \\
\hline Dipatalo & Campylandra aurantiaa Baker & Rhizomes & MCF & Tonic in stomach disorders & 93.5 & 47.6 \\
\hline Doni-homgkang & Plantago erosa Wall & Leaves & MCF & Improving digestion & 19.8 & 7.5 \\
\hline Fayong & Polygonum nepalens Meissn & Leaves & $H G$ & For sick persons & 87.5 & 36.0 \\
\hline Gende & Gynura crepidioides Benth & Leaves & $H G$ & For sick persons & 96.6 & 41.5 \\
\hline Haryo & Eryngium foetidum L. & Stem and leaves & $H G$ & Headache and madness & 87.2 & 39.7 \\
\hline Kadokaro & Drymaria diandra $\mathrm{Bl}$ & Fruits & MCF & Gastric problem & 86.2 & 40.5 \\
\hline Kekir & Zingiber siangensis & Rhizome & MCF & $\begin{array}{l}\text { Cough and cold, wound healing, } \\
\text { and in snake bites }\end{array}$ & 85.5 & 57.8 \\
\hline Koppi & Solanum torvum Swartz & Fruits & $H G$ & Gas and indigestion & 80.2 & 60.0 \\
\hline Koppir & Solanum khasianum Clarke & Fruits & $H G$ & Gas and indigestion & 79.5 & 62.0 \\
\hline Kulu & Musa sapientum L. & Fruits & MCF & Swollen feet and skin disorders & 27.9 & 9.5 \\
\hline Lalada & Zingiber sp. Roscoe & Rhizome & $H G$ & Cough and cold, wound healing & 80.4 & 43.8 \\
\hline Mamang & Physalis minima L. & Leaves & $H G$ & For sick person & 78.2 & 47.6 \\
\hline Namdung & Perilla ocymoides L. & Seeds & $J \mathrm{~L}$ & $\begin{array}{l}\text { Stomach disorders and supplementary } \\
\text { food for pregnant women }\end{array}$ & 97.5 & 58.5 \\
\hline Nayang & Erigeron canadensis $\mathrm{L}$. & Leaves & $J$ & For sick persons & 27.3 & 9.5 \\
\hline Oik & Pouzolzia hirta Hassk & Leaves & $H G$ & Improving lactation & 68.4 & 33.2 \\
\hline Onger & Zanthoxylum rhetsa Roxb. & Leaves & $H G$ & $\begin{array}{l}\text { Stomach disorders and high blood } \\
\text { pressure }\end{array}$ & 66.8 & 45.7 \\
\hline Ongin & $\begin{array}{l}\text { Clerodendrum colebrookianum } \\
\text { Walp. }\end{array}$ & Leaves & $H G$ & $\begin{array}{l}\text { Controlling high blood pressure } \\
\text { and diabetes }\end{array}$ & 65.8 & 39.8 \\
\hline Paput & Gnepalium affine D. Don & Leaves & $H G$ & For getting quick energy & 59.2 & 28.5 \\
\hline Rouri & Piper sylvaticum Roxb. & Leaves & $H G$ & Sick person & 65.9 & 30.0 \\
\hline Rukdik & Thelypteris glanduligera Kunze & Leaves & MCF & Muscle pain & 34.2 & 14.9 \\
\hline Rumdum & Blumea fistulosa Roxb. & Leaves & MCF & Diarrhea & 32.5 & 7.8 \\
\hline Sajna & Moringa oleifera Lam. & Pods and leaves & $H G$ & control muscle pain and diarrhea & 30.2 & 12.5 \\
\hline Satabayom & Solanum indicum $\mathrm{L}$. & Fruits & $\mathrm{HG}$ & Diabetes & 77.8 & 51.4 \\
\hline Sirang & Castanopsis kurzii Hance & Fruits & $J \mathrm{~L}$ & $\begin{array}{l}\text { Alleviating scurvy, gas trouble, } \\
\text { and toothache }\end{array}$ & 34.6 & 13.7 \\
\hline Talab & Allium sp. L. & Bulbs & $H G$ & Improving digestion & 75.4 & 49.5 \\
\hline Tangmeng & Mussaenda roxburghii Hook. f. & Leaves & MCF & Stomach disorders & 47.9 & 30.0 \\
\hline Tangum & Bidens pilosa $\mathrm{L}$. & Leaves & $J$ & Sick persons & 39.2 & 12.5 \\
\hline Teetbaigan & Solanum kurzii Brace & Fruits & $\mathrm{J}$ & Improving digestion & 38.7 & 14.5 \\
\hline Toko-patta & Livistona jenkinsiana Griff. & Fruits & $J \mathrm{~L}$ & Gastric problems & 37.4 & 18.0 \\
\hline Statistics & & & & $t$ value $=5.11, p<0.000$ & & \\
\hline
\end{tabular}

JL Jhum lands, HG home gardens, MCF Morang community forest

a Leaf parts data: Leaves = $15(45.45 \%)$; fruits = $9(27.27 \%)$; flower, peel, seeds, stem, bulbs, and pods $=6(18.18 \%)$; rhizomes $=3(9.09 \%)$

${ }^{b}$ Habitat data: $\mathrm{JL}=8$ species $(24.24 \%), \mathrm{HG}=15$ species $(45.45 \%) ;$ MCF $=10$ species $(30.30 \%)$

${ }^{\mathrm{C}}$ Multiple responses 


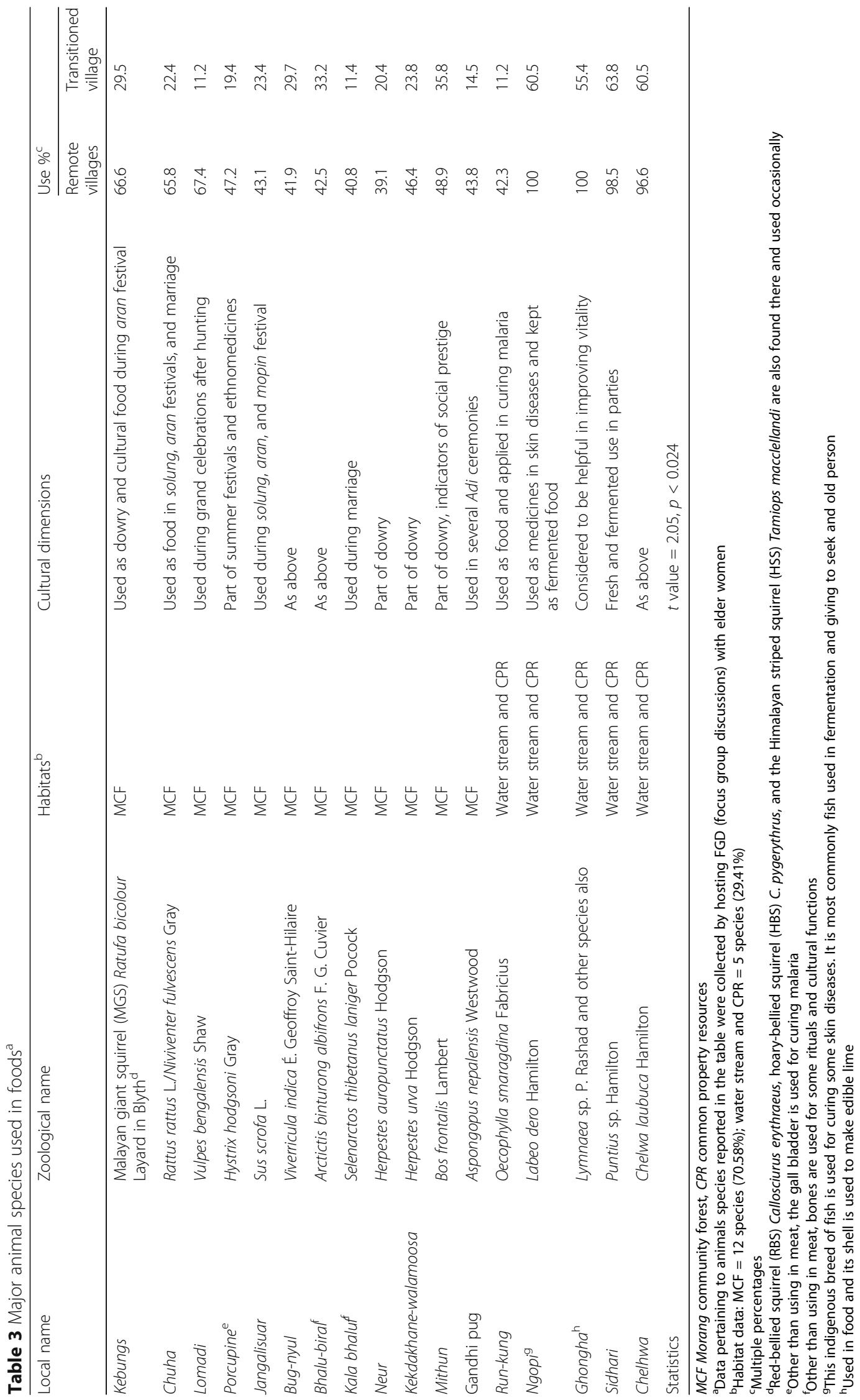


55.4\%) in transition villages. Sidhari (Puntius sp.) and chelhwa (Chela laubuca) fish were the second and third most used food species: 98.5 and $96.6 \%$ use, respectively, among the women of remote villages, and 63.8 and $60.5 \%$ among women of transitional villages. Among insects, the gandhi-pug (Aspongopus nepalensis) was used more widely as food $(43.8 \%)$ in remote villages than in transitional villages (14.5\%). These animal-based food species were integral parts of various Adi socio-cultural dimensions (festivals, marriage, and ethnomedicines). Overall, their use as food was significantly higher in remote than transitional villages $(t=2.05, p<0$. 024).

Most of the terrestrial animal species across the two community types were accessed from morang community forest (being hunted by the men and provided to the women) $(70.58 \%)$, while aquatic species, caught by both men and women, came from freshwater streams and community rivers (common property resources) (29.41\% use). Proximity to morang forest and other common property resources enables the Adi of remote villages to hunt listed species more frequently than in transitioning villages. In addition, women living nearby jhum lands, especially in remote communities, were able to use local landraces of rice (local variety amkel and geku) for making fermented rice and taken with fish, animal, and ethnobotanical products.

\section{Dietary shift from traditional to "convenience" foods}

Some of forest-based foods harvested and used by $A d i$ women have made the transition from being considered hardship fare to being delicacies fit for social and cultural celebrations. Examples include ongin
(Clerodendrum colebrookianum), onger (Zanthoxylum rhetsa), kopi (Solanum torvum), koppir (Solanum khasianum), and bangko (Solanum spirale). Nevertheless, the use of forest-based foods has decreased over time (Fig. 4). The majority of respondents (79.8\%) noted a higher abundance of deer, rabbits, boar, and forest rodents in the 1970s and earlier. With evergrowing population, changing land use pattern, acculturation, and an erosion of traditional conservation values, the populations of these wild animals have generally declined. Women reported that the jhum lands, following the cutting of trees, have become drier than in the recent past, and described numerous declines over the past few decades in wildlife abundance and in plant-based traditional foods around the settlements, especially in the transitional villages.

Use of some fiber species in food was greater among Adi women of remote areas. For example, only 5-7 fiberrich species were used by Adi women of transitional villages, whereas in remote locations use of 20-25 such species were documented. In transitional villages, people were consuming only $20-25 \%$ boiled foods, with diets rich in fried and fast foods (30-40\%), whereas in more remote locations mostly boiled food without spices and marketed oil were consumed. In remote communities, fat was mainly obtained from hunted animals, and plants like sayong, kekir, onger, and dilap were used as spices and flavoring the food. Women of transitional villages use purified table salt (chemically sodium chloride without trace minerals), while in remote areas, women used natural salts and ash (produced from burning snail shells); presumably rich in both sodium chloride and other minerals.

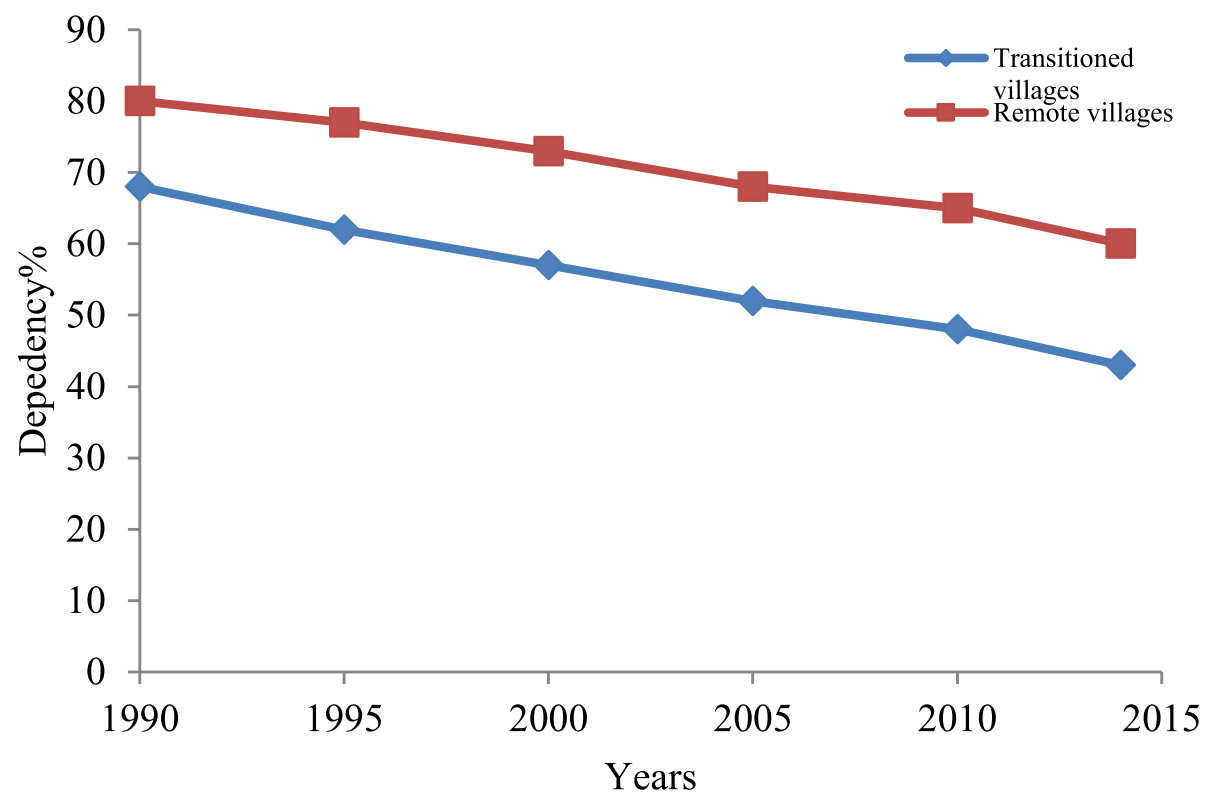

Fig. 4 Dependency percentage of Adi on forest-based traditional foods over the year near town and in remote villages 
Role of plant species in food and income security

We identified, in all, 13 economically important species harvested by Adi women for income, markedly reduce their dependency on external resources (Table 4). These species are adapted to multiple stressors including climatic (flood), ecological (e.g., soil acidity), and institutional (poor accesses of formal institutions and organized market). These species become particularly significant at times when low-lying areas are hit by floods/flash floods, and supplies of marketed foods are curtailed. These species are available in different seasons and vary in economic value, from as low as INR $45 / \mathrm{kg}$ to INR $200 / \mathrm{kg}$. However, women of remote areas fetched relatively lower returns from their sale compared to those from transitional village women having access to town markets. For example, the highest difference in market price between remote and transitional villages (109.67\%) was recorded for lalada (Zingiber sp.), while lowest was for rouri (Piper sylvaticum) (42.86\%) (Table 4). There was a significant difference $(t=2.94, p<0.003)$ for the overall market price of 13 species between these two women's groups.

These species were accessed primarily from jhum lands (53.84\%) and combinations of jhum lands, home gardens, and morang community forests (23.08\%). The Adi women of remote villages-often having more family members to collect these local species from different ecosystems-sell them at lower prices to women living near towns. These women augment the diversity of food plants to some extent from their own land use systems, and diversify market demand by assigning different grades (e.g., single species, mixture of two species, mixture of 3-6 species, and mixture of sometimes 7-12 species) to the plant products, according to customer preferences and the price these mixtures bring. The women of transitional villages earned an average of INR 60,000 to 80,000 (US\$ 943.1 to 1100 ) per year by selling such local plants, while women of remote villages earned less (INR 35,000 to 50,000; US\$ 487.74 to 696.77).

\section{Species diversity, and agronomic and cultural practices for conservation \\ Diversity and similarity indices of Adi food species}

The Shannon index revealed that with species richness of 8 , the diversity $(H)$ of food plants was higher in home gardens (2.08) with similarity index $(1-D)$ of 0.88 , followed by jhum lands $(H=1.79 ; 1-D=0.83)$. Across

Table 4 Economically important ethnobotanicals used by Adi women for food and income

\begin{tabular}{|c|c|c|c|c|c|c|c|}
\hline \multirow[t]{2}{*}{ Local name } & \multirow[t]{2}{*}{ Scientific name } & \multirow[t]{2}{*}{ Habitat $^{a}$} & \multirow[t]{2}{*}{$\begin{array}{l}\text { Seasonal } \\
\text { availability }\end{array}$} & \multicolumn{2}{|c|}{$\begin{array}{l}\text { Economic value in } \\
\text { INR }^{\mathrm{b}} \text { per } \mathrm{kg}\end{array}$} & \multirow[t]{2}{*}{ Difference \% } & \multirow[t]{2}{*}{ Role in adaptations } \\
\hline & & & & $\begin{array}{l}\text { Remote } \\
\text { villages }\end{array}$ & $\begin{array}{l}\text { Transitioned } \\
\text { village }\end{array}$ & & \\
\hline Koppi & Solanum torvum & $J \mathrm{~L}$ and $\mathrm{HG}$ & April to September & 70.0 & 38.0 & 84.21 & A dependable food during flood ${ }^{c}$ \\
\hline Koppir & Solanum khasianum & $J \mathrm{~L}$ and $\mathrm{HG}$ & April to September & 65.0 & 31.0 & 109.67 & As above \\
\hline Onger & Zanthoxylum rhetsa & $\mathrm{JL}, \mathrm{HG}$, and MCF & Year round & 75.0 & 40.0 & 87.50 & $\begin{array}{l}\text { Used year round. Stored after } \\
\text { drying for off-season use }\end{array}$ \\
\hline Pumpkin & Cucurbita moschata & \lrcorner $L$ & April to August & 45.0 & 20.0 & 125.00 & Easily cultivable \\
\hline Lalada & Zingiber sp. & $J \mathrm{~L}$ and $\mathrm{HG}$ & May to October & 120.0 & 50.0 & 140.00 & Medicinal and used as cash crop \\
\hline Kekir & Zingiber siangensis & \lrcorner & May to October & 200.0 & 100.0 & 100.00 & Medicinal and used as cash crop \\
\hline Poi & Basella rubra & $J \mathrm{~L}$ and $\mathrm{HG}$ & April to August & 50.0 & 32.0 & 56.25 & A dependable food during flood \\
\hline Dhekia saag & $\begin{array}{l}\text { Diplazium } \\
\text { esculentum }\end{array}$ & $J \mathrm{~L}$ and MCF & May to September & 60.0 & 32.0 & 87.50 & As above \\
\hline Marshang & Spilanthes acmella & $\mathrm{J}, \mathrm{HG}$, and MCF & April to August & 45.0 & 28.0 & 60.71 & Compatible to grow anywhere \\
\hline Ongin & $\begin{array}{l}\text { Clerodendrum } \\
\text { colebrookianum }\end{array}$ & $\mathrm{J}, \mathrm{HG}$, and MCF & May to October & 100.0 & 55.0 & 81.82 & $\begin{array}{l}\text { Medicinal and can be used year } \\
\text { round. Can be stored after drying } \\
\text { for off-season use }\end{array}$ \\
\hline Kalmu & A creeper & $J \mathrm{~L}$ and $\mathrm{HG}$ & May to September & 65.0 & 35.0 & 85.71 & $\begin{array}{l}\text { Easy in growing and no inputs } \\
\text { are required }\end{array}$ \\
\hline Rouri & Piper sylvaticum & $J \mathrm{~L}$ and $H G$ & May to September & 60.0 & 42.0 & 42.86 & $\begin{array}{l}\text { Easy in growing and no inputs } \\
\text { are required }\end{array}$ \\
\hline Adi dhania & Eryngium foetidum & $J \mathrm{~L}$ and $\mathrm{HG}$ & April to November & 100.0 & 55.0 & 81.82 & $\begin{array}{l}\text { Used as substitute for many } \\
\text { vegetables. Can be stored after } \\
\text { drying for off-season use }\end{array}$ \\
\hline Statistics & & & $t=2.94, p<0.0035$ & & & Overall 89.69\% & \\
\hline
\end{tabular}

JL, Jhum-land; $H G$, home gardens; MCF, Morang community forest

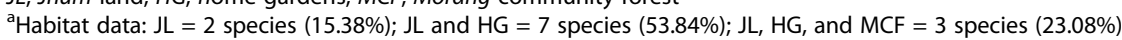

$\mathrm{b}_{1}$ USD = 71.76 INR

'Since these species are grown at higher altitude in mountainous ecosystems, that is why the flood does not affect these species 
these two land use systems, with species richness 14 (Chao-2 $=34.62 \pm 26.23$ ), the diversity was 2.64 with a similarity index of 0.93 (Table 5). With regard to plant species used for both food and ethnomedicine, the diversity (2.71) with species richness 15 was again highest in home gardens, with similarity index of 0.93 as compared to morang community forest $(H=2.40 ; 1-D=0.78)$, having 11 species, and jhum lands $(H=1.95 ; 1-D=$ $0.86)$ with 7 species. Across the three land use systems, with species richness of 33 (Chao- $2=101.5 \pm 148$ ), the diversity was 3.50 , and the similarity index 0.03 . In case of animal-based food species, with species richness 12 , the morang community forest demonstrated higher diversity index (2.49) with similarity value of 0.92 than those of 5 species being accessed from aquatic bodies. With species richness 17 , we noted species diversity 3.85 with Chao- 2 value $45.49 \pm 38.29$. Overall, the species diversity was higher in animal species (3.85), followed by dual-purpose plant species (food and ethnomedicines) (3.50) and species used only for food (2.64). The BergerParker index revealed that proportional abundance of species for food and for dual purpose (food and ethnomedicine) was higher in jhum lands as compared to other land use systems. In case of animal species used as food, Berger-Parker index (0.20) was greater for species accessed from aquatic body.

\section{Agronomic practices}

We found that a great majority (90.7\%) of women from remote villages practiced mixed cropping along with relay cropping (62.5\%) as traditional agronomic practices. These numbers were fewer among their counterparts in transitional villages ( $40.6 \%$ and $8.5 \%$, respectively). The intended outcomes of these practices were to enhance soil fertility, to strategically use residual soil moisture and to avoid ecological and climatic risks associated with particular species (Fig. 5). Controlled burning (82.4\%), applying activator material $(62.5 \%)$ (elephant and deer excreta) to enrich soil fertility, and active seed dispersal (69.2\%) were key agronomic strategies for women of remote rural areas. The activator material also helped break seed dormancy of uncultivated species and enhanced plant productivity. They were not used by women in transitional villages, and the other practices were less frequent (20.4\%). Similar trends across community types were seen for vegetative propagation, diversifying harvests, applying special planting techniques, and selective harvesting of plant species to enhance plant populations and species diversity. Creation

Table 5 Shannon diversity and similarity indices of bio-culturally important food species of Adi

\begin{tabular}{|c|c|c|c|c|}
\hline \multirow[t]{2}{*}{ Major use } & \multicolumn{4}{|c|}{ Diversity and similarity indices } \\
\hline & Jhum lands & Home gardens/aquatic bodies ${ }^{a}$ & Morang community forests & Across the ecosystems \\
\hline \multicolumn{5}{|l|}{ A. Food } \\
\hline \multicolumn{5}{|l|}{ A.1 Plant species } \\
\hline Species richness & 6 & 8 & NA & 14 \\
\hline Shannon diversity $(H)$ & 1.79 & 2.08 & NA & 2.64 \\
\hline Simpson dominance $(1-D)$ & 0.83 & 0.88 & NA & 0.93 \\
\hline Berger-Parker index & 0.17 & 0.13 & NA & 0.08 \\
\hline Chao-2 & - & - & - & $34.62 \pm 26.23$ \\
\hline \multicolumn{5}{|l|}{ A.2 Animal species } \\
\hline Species richness & NA & 5 & 12 & 17 \\
\hline Shannon diversity $(H)$ & NA & 1.61 & 2.49 & 3.85 \\
\hline Simpson dominance $(1-D)$ & NA & 0.80 & 0.92 & 0.98 \\
\hline Berger-Parker index & NA & 0.20 & 0.08 & 0.02 \\
\hline Chao-2 & - & - & - & $45.49 \pm 38.29$ \\
\hline \multicolumn{5}{|l|}{ B. Food and ethnomedicine } \\
\hline Species richness & 7 & 15 & 11 & 33 \\
\hline Shannon diversity $(H)$ & 1.95 & 2.71 & 2.40 & 3.50 \\
\hline Simpson dominance $(1-D)$ & 0.86 & 0.93 & 0.78 & 0.97 \\
\hline Berger-Parker index & 0.14 & 0.07 & 0.09 & 0.03 \\
\hline Chao-2 & - & - & - & $101.5 \pm 148$ \\
\hline
\end{tabular}

Note: NA indicates that there were no species recorded in that particular land use

Looking to the assumptions of diversity indices (sample size and number of species for each category), pooled data (across the social systems) were used to draw this table

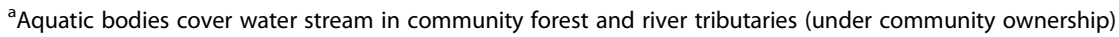




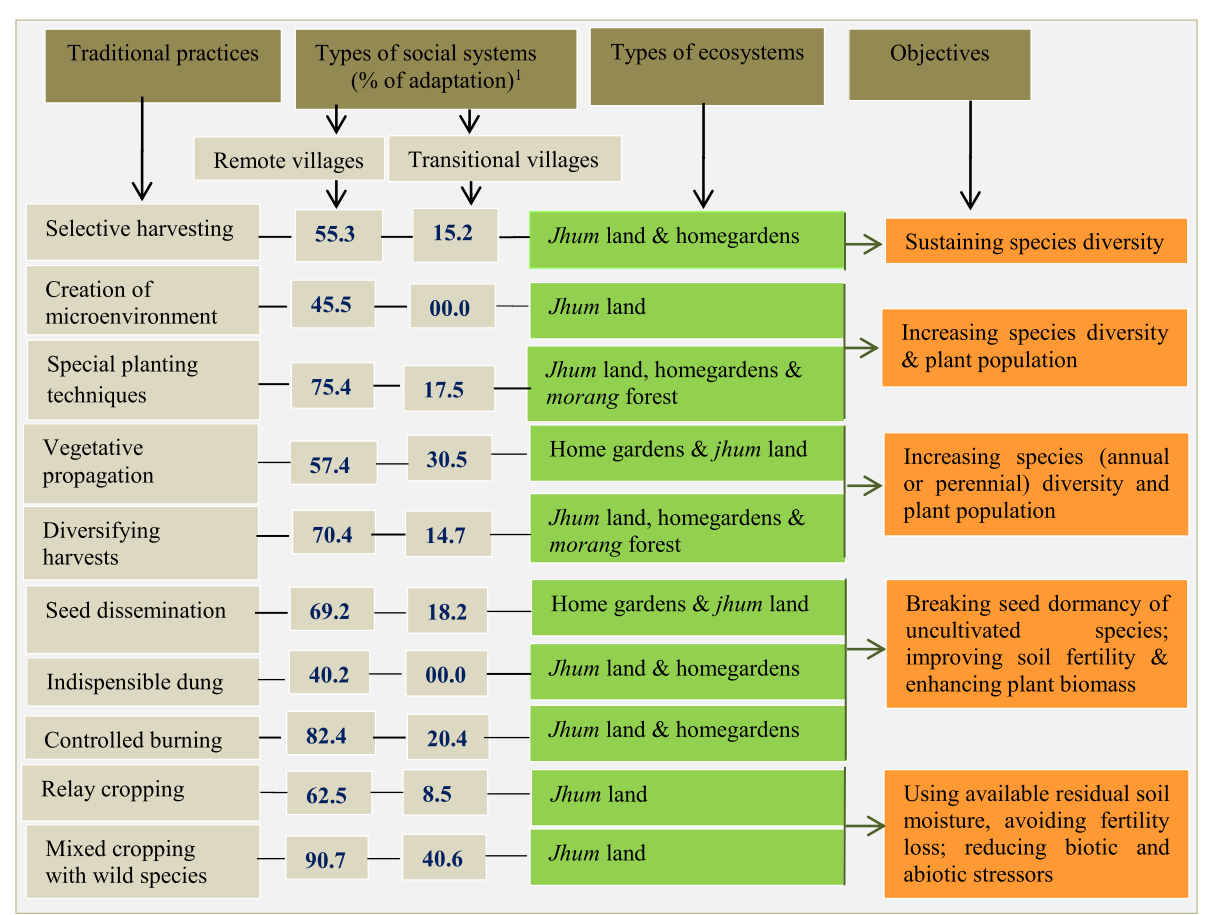

Fig. 5 Traditional agronomic practices adapted by Adi women to enrich plant species diversity and enhance ecological sustainability. ${ }^{1}$ Figure is based on pooled data of FGDs conducted in each village

of micro-environments (e.g., using exhausted edges of bamboo groves, and digging trenches and lining them with sisar tree wood) (45.5\%) to increase species diversity and plant populations was an uncommon practice among women of remote villages and not practiced at all among women of transitional villages. All these traditional practices varied across the ecosystems surveyed (jhum land, morang forest, and home gardens) (Fig. 5).

\section{Food-based knowledge learning}

Acquiring knowledge about a particular food and its component species requires incremental experiential learning and practice, which Adi women have achieved with the support of various institutions and means (Fig. 6). In remote settlements, family, community, and sociocultural institutions (relep, an informal institution of women, and Kebang, headed by Gaon Burha) were major venues of food knowledge transfer, whereas in transitional villages food networks were more prominent. Mothers were a valuable source of learning about cultural foods for both the social groups, although the relative importance of these modes of learning varied considerably across both systems.

\section{Sociocultural and institutional practices on animal- and plant-based foods}

The women of remote settlements held beliefs that foster conservation of the traditional food species, less so for their transitional village counterparts (see Additional file 1: Table S5). For example, unlike $70.1 \%$ of the remote village participants, only $18.2 \%$ of transitional village participants reported that certain fish species are not given to children, due to a belief that this would cause them to urinate in bed, even after they had grown up. Similarly, $89.8 \%$ of remote village women, but only $35.0 \%$ of transitional village women, maintained that mithun (Bos frontalis) - a semi-wild animal-is culturally precious and must be carefully treated and never killed without a cultural reason. In remote villages, $56.9 \%$ of respondents said that when a wife is pregnant, a male hunter should not hunt monkeys, or they would be haunted by evil spirits, whereas only $23.5 \%$ of transitional village respondents held this belief. When they are in the forest at times of their wives' pregnancy, hunters must avoid drinking water from forest water streams, using Colocasia leaves for drinking, lest their unborn baby would be attacked by evil spirits. This belief was held by $69.4 \%$ of women in remote villages but only $27.0 \%$ of transitional villages in transitions. In the event of any of tabooed species being used as food (listed in Additional file 1: Table S5) by mistake, kekir (a local variety of ginger) is eaten to drive away the resulting evil spirits. Through practicing these beliefs, the demand for harvesting certain plants and animals is minimized for specific periods, particularly in the remote communities. 


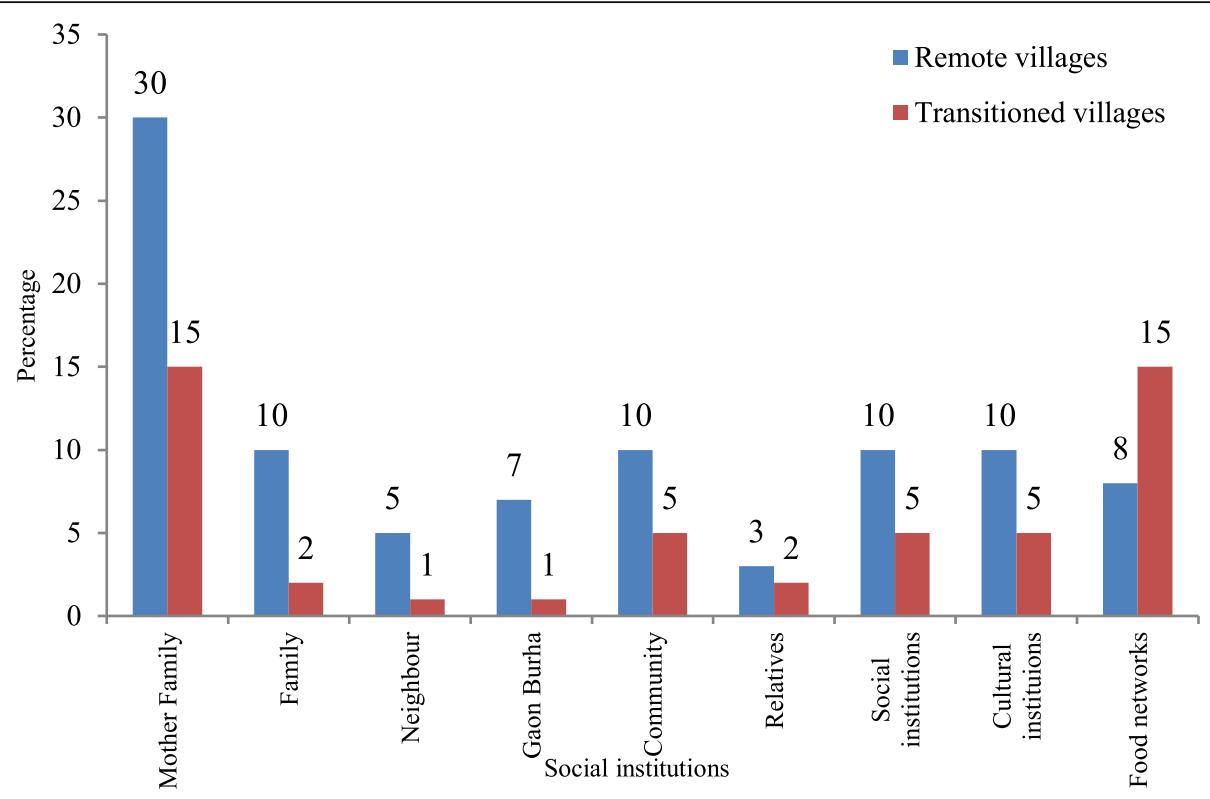

Fig. 6 Intergenerational knowledge transfer through various institutions

Some of the Adi festivals such as solung, aran, and mopin are especially dedicated for hunting; in particular, over-populated animals (e.g. rodents and squirrels [kebungs]) are hunted across the social systems. More families in remote $(62.5 \%)$ than in transitional villages $(28.5 \%)$ mentioned that they avoid hunting female game animals (e.g., kebungs) or catching fish during their breeding periods and that they varied their hunting locations to avoid overhunting. As a result, bioresources formerly used indiscriminately have now received priority for conservation. In addition, sustainability of local biodiversity is maintained by indigenous institutions, including Kebang (led by men) and Reglep (led by women). These play a significant role in regulating hunting and fishing, and harvesting of forest resources, with violators being fined.

\section{Correlation of use and conservation of species}

We found a highly significant correlation between the use and conservation of plant species for both food and ethnomedicine $(0.924, p<0.000)$, and the communities gave greater emphasis on conserving these species in diverse ecosystems (jhum land, home gardens, and morang forests) than for those used only for food $(0.632, p<$ 0.015) (Table 6). The correlation between use and conservation of animals used for food was also appreciably high $(0.832, p<0.0005)$.

\section{Discussion}

Two key points arise from this research: first, how culturally rich plant and animal species are used and accessed for food, ethnomedicine, and livelihood security by $A d i$ women and secondly, how the insights of $A d i$ women in our study can benefit several targets of Sustainable Development Goals (SDGs) and environmental policies in India.

\section{Biocultural resources: food and livelihood security}

Locally harvested plants and animals are important culturally and nutritionally, enhancing health and livelihood security for Adi women and their families. Turner and Clifton (2009) and Maffi (2010) reported that local biodiversity is a backbone for cultural identity and overall livelihood security of indigenous peoples across the globe. We found that Adi women from different social backgrounds (i.e., from remote versus transitional communities) did not necessarily use and access food species in the same way. Women of remote communities in general used more local plant and animal species than those of transitional villages. This difference might be due to variations in upbringing, different ways of coping with time and labor constraints in food production, and differing degrees of access to marketed food (Power 2008; Mishra et al. 2009). Different local strategies were applied by Adi women in accessing food species from different land use types (Turner 2005; Reyes-García et al. 2009). A number of plant species documented were used for both food and ethnomedicine, and this was particularly notable for the remote areas. Our work supports other research showing that local plants and wild game are generally beneficial for the overall nutrition, health, and well-being of indigenous peoples (Kuhnlein et al. 2013; Samson and Pretty 2006). Gregory (2000), Kuhnlein (1980), Kuhnlein (2005), and Kuhnlein et al. (2013) reported that wild plant 
Table 6 Association between usage and conservation of species

\begin{tabular}{llll}
\hline Biocultural usage of species & Sample size & Spearman rank statistic $(r)$ & Significance $(p$ value $)$ \\
\hline Plant species used in food & 14 & 0.632 & $0.015^{*}$ \\
Plant species used both as food and ethnomedicines & 33 & 0.924 & $0.000^{* *}$ \\
Animal species used as food & 17 & 0.832 & $0.0005^{* *}$ \\
\hline
\end{tabular}

"*" and "**" indicate significance at 0.05 and 0.001 probability levels, respectively

Data were analyzed for across the systems (remote and villages under transitions). Categorization in rural and semi-rural was not possible due to statistical assumptions of spearman correlation statistics to avoid misleading conclusions

foods are typically higher in calcium, iron, magnesium, and vitamin $\mathrm{C}$, for example, than cultivated plants. Further, Gregory (2000) suggested that wild fish has less fat, and in particular, less saturated fat, than farm-raised fish. On a worldwide scale, the potential of local species that can be employed as staple foods or in medicinal treatments is very high (Bartlett et al. 2007). While this is especially true for people of remote areas still little affected by planned knowledge, use of local resources also offers many opportunities for enhancing the wellbeing of town and city dwellers. We found a distinct change in Adi peoples' food systems over the last few decades, as is occurring in people's food systems worldwide, which have been transformed at an unprecedented rate due to globalization: a phenomenon termed the "nutrition transition" (Kuhnlein 1980; Bartlett et al. 2007; Power 2008).

We found that women living in transitional social systems closer to urban centers had knew less about traditional ways of cultivating, harvesting, and using local food resources from diverse ecosystems, and used fewer of these foods (cf Turner and Turner 2004; Singh et al. 2010). As a result, their resilience to health and environmental risks is expected to magnify from the erosion of biocultural diversity and the shift away from nutritionally rich local foods to marketed foods, which are often high in unhealthy fats and sugars (Turner and Clifton 2009). Irrigated and mono-cropping systems and implementation of PDS (public distribution system) in India (Kothari 1997), along with emergence of new food stocking and distribution patterns (Behera et al. 2016) with the easy availability of commercial and marketed foods, offer seemingly more efficient alternatives for the people living in or nearby towns, who previously used primarily local and uncultivated species (Kothari 1997). The detrimental effects of new and changed globalized diets are reflected not only in the poorer health of individuals, but also in the farming systems and management of local ecosystems (Parks et al. 2005; Nautiyal et al. 2007).

\section{Biodiversity, conservation, and sustainability}

Strategically, the Adi access food resources from diverse ecosystems in different seasons and practice a variety of ways that conserve and sustain these resources.
Nonetheless, the variety of foods and the extent of conservation practices vary with social differences, especially in relation to proximity to urban centers. We found a significant correlation between use and conservation of food species. Home gardens (species used for only food), morang community forests (species used for both food and ethnomedicines), and common resource areas (aquatic bodies and morang community forests) were the major land use types where diversity of species was higher across both remote and transitional Adi communities. Conservation strategies were further augmented with traditional agronomic practices, varying from one social system to another. Studies have confirmed that in mountainous ecosystems, local biodiversity being conserved in traditional land use systems contributes significantly to overall biodiversity (Jiang et al. 2003) as compared to the more intensive land use systems where exotic species are grown intensively (Parks et al. 2005).

Cultural practices are governed through beliefs and value systems, and supported by indigenous institutions that shape human behavior in the extraction of plant or animal resources, thus influencing conservation outcomes (Berkes 2017). We found a number of plant species with very high cultural values. Use and conservation of food species governed through cultural practices, socio-ecologically and economically compatible with Adi food traditions, might have been enhanced by their location in remote, fragile mountainous ecosystems, and also their need to ensure that local resources from diverse ecosystems are available consistently (cf Charnley et al. 2007). However, recent changes in ecological processes, such as reduction in the jhum land cycle due to the increasing human population (Ramakrishnan 2007), conversion of community forests to commercial fields (e.g., fruit orchards), and changes in social norms, are altering the food habits of local community in Ar P (cf Sobrevila 2008). However, the National Biodiversity Strategy Action Plan and Greening India policies, in which women's participation and knowledge are being incorporated in planning and programs on biodiversity conservation (GOI 2019) show promise. The Indian policy of "Sustaining Himalayan Ecosystems", which considers land use change and other environmental factors as challenges to biodiversity conservation, may draw 
insights from these findings to improve conservation outcomes (GOI 2010).

\section{Insights for Sustainable Development Goals (SDGs)}

Despite the fact that women are creative in adding value to plant and animal species by cultivating and using them as nutritionally rich foods and ethnomedicines, their knowledge has been given little attention in the science and policy initiatives of Ar P (GOI 2007). One target of SDGs, "No Poverty", calls on giving equal rights and opportunity to vulnerable people, including women, for management of land and other natural resources to enhance resilience against several environmental stressors (UN 2019). A key result would be to provide opportunities for involving such women, with their different concerns and needs, in the "bottom-top" approaches for conservation, development, and overall community well-being (Shimla Declaration 2009). SDG targets two ("Zero Hunger") and fifteen ("Life on Land") call on participation of local stakeholders to strengthen policy and actions required to meet food security, biodiversity conservation, and arresting land degradation (UN ibid; UNESCO 2016a; UNESCO 2019). Engaging women and using their knowledge about access to food resources and their conservation practices thus become crucial inputs to various agencies in order to meet targets for sustainable development (Turner and Clifton 2009; UNESCO 2016b). Our results also hold practical utility as knowledge and practices for plant and animal biodiversity management reported herein can be used for formulating location-specific conservation and genetic improvement programs (e.g., selection for diverse traits) and agronomic manipulations for halting biodiversity erosion and land degradation. Ironically, despite their efforts in managing land and biodiversity resources in ecologically harsh situations, such tribal communities seldom receive policy attention and attendant benefits like equitable benefit sharing for biodiversity conservation.

Empowerment of Adi women through locationspecific educational endeavors is vital. Culturally responsive education on traditional foods and associated knowledge will be a prerequisite (Blanchet-Cohen and Reilly 2013) to further strengthen the legacy of conserving biocultural resources with emphasis on achieving SDG targets (especially 1, 2, and 15). For this, women's roles within the school education system need to be defined to ensure knowledge transfer and research promotion, in order to provide a scientific and technical base for supporting government policies (Kuhnlein et al. 2013; UNESCO 2016a). Motivating younger women, particularly from transitional systems, to learn from their elders about traditional food-related knowledge, and to form self-help groups (SHG) for value addition and income generation can strengthen the sustainability of biocultural diversity while meeting several SDGs.

\section{Conclusions and policy implications}

Our study has demonstrated that Adi women, particularly those living in more remote communities, possess a rich knowledge about nutritionally important local food species and their traditional products. They rely heavily on local plant and animal species accessed from diverse land use systems and conserved using proven traditional practices. We found that 14 different plant species were used as food, 33 as both food and ethnomedicine, and 13 species were one of the major means to generating income. Furthermore, we noticed that 17 animal species also play crucial roles in food and sustaining cultural identity of the Adis. The knowledge on integrated strategies applied by Adi women for accessing and using food resources was found to improve biocultural diversity and social-ecological resilience. Women respondents from traditional and transitional villages differed significantly with each other for use of plant and animal species for food, ethnomedicine, and income generation, with the former using significantly more number of species. Similarly, women from traditional villages had more knowledge on species conservation practices than their transitional counterparts. Home gardens were the most important source of diverse food plants, followed by jhum lands. Morang community forests and home gardens displayed more species diversity than other land use systems. Unfortunately, changing life styles and land use patterns have accelerated the erosion of biocultural knowledge; particularly in and around transitional villages. Based on key findings, following recommendations, covering socio-economic and ecological dimensions, can be of considerable relevance to future policy initiatives on sustainable development in fragile mountainous and similar ecosystems:

1. Promotion of reciprocal learning between formal and informal knowledge systems can enhance the adaptive capacity of local communities to cope with emerging social-ecological stressors and provide new avenues to science-policy establishments for improving outcomes vis-à-vis SDGs. Increased participation of custodians of biocultural resources, for example, can improve the local acceptability and outcomes of programs like "Organic Farming Policy" (2005) intended to achieve intertwined objectives of social-ecological resilience and well-being.

2. Emphasis also needs to be placed on promoting local/regional dialects as means for rapid diffusion of biocultural knowledge, especially in areas where social-ecological changes are taking a toll natural capital and livelihoods. For example, creation of "Village Knowledge Banks" in collaboration of 
science-policy institutions, while retaining local identities and ownership of resources, can provide localized education and learning platforms, particularly in areas rich in biocultural resources but facing threats.

3. There is a need for relevant provisions in government policies and programs [e.g., mid-day meal and public distribution system (PDS)] for promoting nutritional local food. Consequent increase in demand for the locally produced nutritious food can motivate the communities for strengthening species conservation measures as well as increasing livelihood opportunities.

4. Special empowerment drives need to be launched for the capacity building of disadvantaged women groups (e.g., Adi women in our case) through Indian policies on promotion of micro and small industries, food processing and value addition, skill development, and eco-tourism such that they are not only better equipped for livelihood security in face of looming threats but may also contribute to achieving some targets of SDGs and biodiversity conservation policies.

5. Coordinated planning between agriculture (including horticulture), forestry, land development corporations, and housing authorities remains critical to reversing and arresting the adverse impacts of land use changes and erosion in biocultural diversity. Aligning local conservation practices with flagship national programs (e.g., Sustaining Himalayan Ecosystems) can specifically help achieve the SDGs targets of "Zero Hunger" and "Life on the Land".

\section{Supplementary information}

Supplementary information accompanies this paper at https://doi.org/10. 1186/s13717-020-00232-x.

Additional file 1. Characteristics of sampled Adi women; major aspects covered in study through pilot testing of interview schedule; visits conducted to various food production/conservation systems (recording and validating species); participatory rural appraisals tools applied in recording data; and beliefs and traditional practices prevalent among Adi women relating to wild animals and some plants used in foods.

Abbreviations

Ar P: Arunachal Pradesh; SDGs: Sustainable Development Goals; TK: Traditional knowledge; SHG: Self-help group

\section{Acknowledgements}

The authors are grateful to local experts, women, and community leaders of Adi tribe who have helped us in building rapport and were an integral part of this study. Taxonomic helps in the identification of plant species were obtained from Botanical Survey of India, Itanagar, Arunachal Pradesh. The authors acknowledge logistic supports obtained from Central Agricultural University, Imphal, Manipur, for conducting field studies, and ICAR-Central Soil Salinity Research Institute, Karnal, India, in preparing this article.

\section{Authors' contributions}

RKS generated the idea and designed the study, collected and analyzed data, and wrote the article. AK, AS, and PS helped in application of study framework, statistical applications, writing, and reading and revising the manuscript. All the authors read and approved this manuscript.

\section{Authors' information}

Ranjay K. Singh is serving as Principal Scientist (Agricultural Extension) at ICAR-Central Soil Salinity Research Institute (CSSRI), Karnal, Haryana, India. His research interest includes human-environment interactions, and he has collaborated with tribal and marginal communities to work out local solutions for community-based natural resource conservation and adaptation to global environmental change. Arvind Kumar is working as a Scientist of crop improvement at ICAR-CSSRI, Karnal, and is specialized in developing crop varieties against abiotic stresses. Anshuman Singh is working as a Scientist at ICAR-CSSRI, Karnal, and has specialization in fruit crops. Poonam Singhal is a Lecturer (Food Science and Technology) at the University of Hyderabad, Hyderabad, India. Her research interests include exploration, characterization and validation of plant-based ethnic foods of India.

\section{Funding}

This study was financially supported by National Innovation FoundationIndia, Ahemdabad and Central Agricultural University, Pasighat, Arunachal Pradesh, India, through research projects on traditional foods and Rural Horticulture Work Experience.

\section{Availability of data and materials}

Substantial amount of data generated and analyzed is covered in the paper. Further, additional data have been provided in online resources. However, corresponding author may be contacted in case of any clarifications required on data under report.

\section{Ethics approval and consent to participate}

Not applicable; however, study participants were informed about the objectives of the study prior to their participation, including the expected outcomes in form of print and digital publications. Accordingly, the consent was obtained in oral form from the studied respondents and Community Chief (Gaon Burha) of study villages on knowledge and practices (including photo) on food species to be published. This study was approved by the institute of affiliation.

\section{Consent for publication}

Not applicable

\section{Competing interests}

The authors hereby declare that they have no competing interests on this article.

\section{Author details}

${ }^{1}$ College of Horticulture and Forestry, Central Agricultural University, Pasighat, Arunachal Pradesh 791102, India. ${ }^{2}$ ICAR-Central Soil Salinity Research Institute, Karnal, Haryana 132001, India. ${ }^{3}$ University of Hyderabad, Hyderabad,

Telangana, India.

Received: 7 February 2020 Accepted: 5 May 2020

Published online: 03 June 2020

References

Aayog NITI (2017) Sustainable Development Goals (SDGs): Targets, CSS, interventions, nodal and other ministries. NITI Aayog, Government of India, New Delhi

Bartlett JG, Modariago-Vignudo L, O'Neil JD, Kuhnlein HV (2007) Identifying indigenous peoples for health research in a global context: a review of perspectives and challenges. Int J Circumpol Health 66(4):287-307

Behera RN, Nayak DK, Andersen P, Elisabeth IE (2016) From jhum to broom: agricultural land-use change and food security: implications on the Meghalaya Plateau, India. Ambio 45:63-77

Berkes F (2017) Sacred ecology, 4th edn. Routledge, New York

Bhardwaj R, Wanghcu L, Sureja AK, Singh RK (2005) Nutritional quality evaluation of ethnic fruits and vegetables. Paper presented in national workshop on 
capacity building of young scientists for nutrition research, held at NIPCCD, Guwahati, Assam (25-28 ${ }^{\text {th }}$ October 2005): 20

Blanchet-Cohen N, Reilly RC (2013) Teachers' perspectives on environmental education in multicultural contexts: towards culturally-responsive environmental education. Teach Teacher Edu 36:12-22

Camargo JA (1997) A rebuttal to: Assessing changes in community structure by dominance indices: a comparative analysis. J Freshw Ecol 12(4):637-641

Charnley S, Fischer AP, Jones ET (2007) Integrating traditional and local ecological knowledge into forest biodiversity conservation in the Pacific Northwest. Forest Ecol Manag 246:14-28

Coddington JA, Young LH, Coyle FA (1996) Estimating spider species richness in a southern Appalachian cove hardwood forest. J Arachnol 24:111-128

Cuthil M (2002) Exploratory research: citizen participation, local government and sustainable development in Australia. Sustain Dev 10:79-89

Danggen B (2003) A book of conversation: a help book for English to Adi conversation. Himalayan Publishers, Itanagar

Davidson-Hunt IJ, Turner KL, Mead ATP, Cabrera-Lopez J, Bolton R, Idrobo CJ, Miretski I, Morrison A, Robson JP (2012) Biocultural design: a new conceptual framework for sustainable development in rural Indigenous and local communities. SAPIENS 5:32-45

DoEF (2010) Forest statistics. Department of Environment and Forest (DoEF), Government of Arunachal Pradesh. http://arunachalforests.gov.in/Forest\%2 OStatistics.html. Accessed 1 Oct 2019

Eguia-Aguilara P, Cruz-Reyesb A, Martinez-Maya JJ (2005) Ecological analysis and description of the intestinal helminths present in dogs in Mexico City. Vet Parasitol 127:139-146

Ellena R, Nongkynrih KA (2017) Changing gender roles and relations in food provisioning among Matrilineal Khasiand Patrilineal Chakhesang indigenous rural people of North-East India. Mat Child Nutri 13(Suppl. 3). https://doi.org/ $10.1111 /$ mcn. 12560

GOI (2007) Biodiversity conservation through community based natural resource management. United Nations Development Programme. Ministry of Environment and Forest, Government of India (GOI). https://www.undp.org/ content/dam/india/docs/biodiversity_conservation_through_community_ based_nrm_project_document_project.pdf. Accessed 28 Feb 2020

GOI (2010) National mission for sustaining the Himalayan eco-system under National Action Plan on climate change. Government of India (GOI). https:// dst.gov.in/sites/default/files/NMSHE_Mission_document.pdf. Accessed 23 Mar 2020

GOI (2019) Implementation of India's National Biodiversity Action Plan (NBSAP)An overview. Ministry of Environment, Forest and Climate Change, Government of India (GOI). http://nbaindia.org/uploaded/pdf/ IndiaNationalBiodiversityActionPlan2019.pdf. Accessed 24 Mar 2020

Gregory C (2000) Native Science: natural laws of interdependence. Clear Light Publishers, Santa Fenm

Gupta AK (1996) Roots of creativity and innovation in Indian society: a honey bee perspective. Wastelands News 12(1):37-68

Gupta AK, Kothari B, Patel K (1999) Networking knowledge-rich, economically poor people. In: World Bank (ed.), Information and communication technology in rural development. Washington, DC: World Bank. http:// documents.worldbank.org/curated/en/543321468338476969/pdf/3892 00Info0and1 cation0200001PUBLIC1.pdf. Accessed 6 Jan 2020

Hammer Ø, Harper DAT, Ryan PD (2001) Paleontological statistics software package for education and data analysis. Paleontologia Electronica (Version 4, 2020) 4(1): folk.uio.no/ohammer/past/. Accessed 18 Mar 2020

IRRI (2013) Statistical Tool for Agricultural Research (STAR), Version: 2.0.1 (20132020). International Rice Research Institute (IRRI), Philippines

Jiang Y, Muyikang GG, Min LH, Xiong ZJ, Jin Z (2003) Impact of land use on plant biodiversity and measures for biodiversity conservation in the Loess Plateau in China - a case study in a hilly-gully region of the Northern Loess Plateau. Biodivers Conserv 12:2121-2133

Joshi G (1989) Forest policy and tribal development. Cultural Survival https:// www.culturalsurvival.org/publications/cultural-survival-quarterly/forest-policyand-tribal-development. Accessed 10 Jan 2020

Kothari A (1997) Conserving India's agro-biodiversity: prospects and policy implications. IIED, London, Gatekeeper 65. http://pubs.iied.org/pdfs/61191|ED. pdf. Accessed 24 Feb 2019

Kuhnlein HV (1980) The trace element content of indigenous salts in comparison to commercially refined substitutes. Ecol Food Nutri 10:113-121

Kuhnlein VH (2005) International Union of Nutritional Sciences Task Force: indigenous peoples. Food systems and nutrition task force report. May, 2005. https://www.mcgill.ca/cine/files/cine/task_force_report_hvk-05.pdf. Accessed 23 Mar 2019

Kuhnlein VH, Erasmus B, Spigelski D, Burlingame B (2013) Indigenous peoples' food systems and well-being interventions and policies for healthy communities. Centre for Indigenous Peoples' Nutrition and Environment, Food and Agriculture Organization of the United Nations. http://www.fao. org/docrep/018/i3144e/i3144e.pdf. Accessed 24 Nov 2018

Maffi L (2010) What is biocultural knowledge. In: Maffi L, Woodley E (eds) Biocultural diversity conservation. Earthscan, London, pp 1-11

Magni G (2016) Indigenous knowledge and implications for the sustainable development agenda. United Nations, Educational, Scientific and Cultural Organization (UNESCO). http://unesdoc.unesco.org/images/0024/ 002456/245623E.pdf. Accessed 24 Dec 2018

Marten GG (2001) Human ecology: basic concepts for sustainable development. Earthscan Publications, London, p 256

Merétika AHC, Peroni N, Hanazaki N (2010) Local knowledge of medicinal plants in three artisanal fishing communities (Itapoá, Southern Brazil), according to gender, age, and urbanization. Acta Bot Bras 24:386-394

Mishra S, Singh RK, Singh A (2009) Dynamics of traditional foods and livelihood of Adi women in varying socio-ecological systems of Arunachal Pradesh: a source of learning and inspiration. In: Lindgreen A, Hingley MK (eds) New cultures of food: Marketing opportunities from ethnic, religious and cultural diversity. Gower Press, UK, pp 203-222

Myer N, Muttermeier RA, Muttermeier CA, da Fornseca GAB, Kent J (2000) Biodiversity hotspots for conservation priorities. Nature 403:853-858

Nagendra H (2002) Opposite trends in response for the Shannon and Simpson indices of landscape diversity. Appl Geogr 22:175-186

Nautiyal S, Kaechele H, Rao KS, Maikhuri RK, Saxen KG (2007) Energy and economic analysis of traditional versus introduced crops cultivation in the mountains of the Indian Himalayas: a case study. Energy 32:2321-2335

Nayar MP (1996) Hotspots of endemic plants of India, Nepal and Bhutan. Tropical Botanic Garden and Research Institute, Thiruvananthapuram, India

Onwuegbuzie AJ, Collins KM (2007) A typology of mixed methods sampling designs in social science research. Qual Report 12(2): 281-316

Orchard SE, Stringer LC, Claire CH (2016) Mangrove system dynamics in Southeast Asia: linking livelihoods and ecosystem services in Vietnam. Reg Environ Chang 16:865-879

Parks CG, Radosevich SR, Endress BA, Naylor BJ, Anzinger D, Rew LJ, Maxwell BD, Dwire KA (2005) Natural and land-use history of the Northwest mountain ecoregions (USA) in relation to patterns of plant invasions. Perspect Plant Ecol Evol Syst 7(3):137-158

Power EM (2008) Conceptualizing food security for aboriginal people in Canada. Can J Public Health 99(2):95-97

Pretty J, Adams B, Berkes F, de Athayde S, Dudley N, Hunn E, Maffi L, Milton K, Rapport D, Robbins P, Sterling E, Stolton TA, Vintinnerk E, Pilgrim S (2009) The intersections of biological diversity and cultural diversity: towards integration. Conserv Soc 7(2):100-112

Ramakrishnan PS (2007) Sustainable mountain development: the Himalayan tragedy. Curr Sci 92(3):308-316

Rao RR (1994) Biodiversity in India: floristic aspects. Bishen Singh Mahendra Pal Singh Press, Dehradun

Reyes-García V, Broesch J, Calvet-Mir L, Fuentes-Peláez N, McDade TW, Parsa S, Tanner S, Huanca T, Leonard WR, Martínez-Rodríguez MR, TAPS, Bolivian study Team (2009) Cultural transmission of ethnobotanical knowledge and skills: an empirical analysis from an Amerindian society. Evol Hum Behav 30: 274-285

Roscoe JT (1975) Fundamental research statistics for the behavioral sciences, 2nd edn. Holt Rinehart and Winston, New York

Samson C, Pretty JN (2006) Environmental and health benefits of hunting lifestyles and diets for the Innu of Labrador. Food Policy 31(6):528-553

Schleicher J, Schaafsma M, Bhaskar V (2018) Will the Sustainable Development Goals address the links between poverty and the natural environment? Curr Opin Environ Sustain 34:43-47

Shimla Declaration (2009) Himalayan Chief Ministers' Conclave Indian Himalayas: glaciers, climate change and livelihoods. Shimla Declaration on Sustainable Himalayan Development, Shimla, October 30, 2009. http://www.hpccc.gov.in/ PDF/Shimla\%20Declaration.pdf. Accessed 23 Mar 2020

Singh RK, Adi W (2010) Biocultural knowledge systems of Adi tribe in eastern Himalaya. NISCAIR, CSIR, New Delhi

Singh RK, Hussain SM, Riba T, Singh A, Padung E, Rallen O, Lego YJ, Bhardwaj AK (2018) Classification and management of community forests in Indian 
Eastern Himalayas: implications on ecosystem services, conservation and livelihoods. Ecol Process 7:27 https://doi.org/10.1186/s13717-018-0137-5

Singh RK, Pretty J, Sarah P (2010) Traditional knowledge and biocultural diversity: learning from tribal communities for sustainable development in Northeast India. J Environ Plan Manag 53(4):511-533

Singh RK, Singh A (2013) Biodiversity and recipe contests: innovative socioecological approaches to capture ecological knowledge and conserve biodiversity in Arunachal Pradesh. Indian J Tradit Knowl 12(2):240-251

Singh RK, Zander KK, Kumar S, Singh A, Sheoran P, Kumar A, Hussain SM, Riba T, Rallen O, Lego YJ, Padung E, Garnett ST (2017) Perceptions of climate variability and livelihood adaptations relating to gender and wealth among the Adi community of the Eastern Indian Himalayas. Appl Geogr 86:41-52

Sobrevila C (2008) The role of indigenous peoples in biodiversity conservation: the natural but often forgotten partners. The World Bank. https:// siteresources.worldbank.org/INTBIODIVERSITY/Resources/ RoleoflndigenousPeoplesinBiodiversityConservation.pdf. Accessed 9 Jan 2020

Stringer LC, Reed MS, Fleskens L, Thomas RJ, Le QB, Lala-Pritchard T (2017) A new dryland development paradigm ground in empirical analysis of dryland science. Land Degrad Dev 28:1952-1961

Subramanian SM, Pisupati B (2010) Traditional knowledge in policy and practice: approaches to development and human well-being. United Nations University Press, Tokyo https://collections.unu.edu/eserv/UNU:2546/ ebrary9789280811919.pdf.

Toledo VM (1999) Indigenous people and biodiversity. In: Levin S, et al. (eds.), Encyclopedia of biodiversity. Academic Press, USA. https://doi.org/10.1016/ B978-0-12-384719-5.00299-9

Turner N, Spalding PR (2013) "We might go back to this": Drawing on the past to meet the future in Northwestern North American indigenous communities. Ecol Soc 18(4):29 https://doi.org/10.5751/ES-05981-180429

Turner NJ (2005) Earth's Blanket: traditional teaching for sustainable living. Douglas and McIntyre Ltd, Vancouver

Turner NJ, Clifton H (2009) It's so different today: climate change and indigenous lifeways in British Columbia, Canada. Glob Environ Chang 19:180-190

Turner NJ, Turner SE (2004) Food, forage and medicinal resources of forests. Encyclopedia of life support systems. EOLSS Publishers, pp 1-41

UN (2019) Sustainable Development Goals (SDGs). United Nation (UN). https:// www.undp.org/content/undp/en/home/sustainable-development-goals.html. Accessed 23 Mar 2020

UNESCO (2016a) Indigenous knowledge and implications for the sustainable development agenda: background paper prepared for the 2016 Global Education Monitoring Report. https://unesdoc.unesco.org/ark:/48223/ pf0000245623. Accessed 9 Dec 2019

UNESCO (2016b) Promoting health and literacy for women's empowerment. United Nations, Educational, Scientific and Cultural Organization (UNESCO). https://unesdoc.unesco.org/ark:/48223/pf0000245698. Accessed 29 Apr 2020

UNESCO (2019) Culture: at the heart of SDGs. United Nations Educational, Scientific and Cultural Organization (UNESCO) https://en.unesco.org/courier/ april-june-2017/culture-heart-sdgs. Accessed 6 Dec 2019

Wagner CS, Alexander J (2013) Evaluating transformative research programmes: a case study of the NSF small grants for exploratory research programme. Res Evaluat 22:187-197

Yadav AK, Tangpu Y (2009) Therapeutic efficacy of Zanthoxylum rhetsa DC extract against experimental Hymenolepis diminuta (Cestoda) infections in rats. J Parasit Dis 33(1\&2):42-47

\section{Publisher's Note}

Springer Nature remains neutral with regard to jurisdictional claims in published maps and institutional affiliations.

\section{Submit your manuscript to a SpringerOpen ${ }^{\circ}$ journal and benefit from:}

- Convenient online submission

- Rigorous peer review

- Open access: articles freely available online

- High visibility within the field

- Retaining the copyright to your article

Submit your next manuscript at $\boldsymbol{\nabla}$ springeropen.com 